\title{
The Effect of Risk Management, Firm Age, and Firm Size on the Performance of Banking Companies Registered in Indonesia Stock Exchange Moderated By Corporate Governance and Budget as Control Variable
}

\author{
Mochamad Muslih ${ }^{1}$, Serina Oktavia Marbun ${ }^{2}$ \\ ${ }^{1,2}$ STIE Tri Bhakti, Indonesia \\ Email:mochamadmuslih@stietribhakti.ac.id
}

\begin{abstract}
The purpose of this study was to study the effect of risk management, company age, and company size on the performance of banking companies listed on the Indonesia Stock Exchange with governance as moderating and budget as control variables. This study uses quantitative methods with multiple regression analysis methods. The population of this study is banking companies listed on the Indonesia Stock Exchange for the period 2013 2018. The sample size is 28 (twenty eight) banking companies listed on the Indonesian Effek Exchange for the observation period of 6 (six) years. The data source is secondary data in the form of annual reports of banking companies listed on the Indonesia Effek Exchange. The results showed that risk management with a prob of $0.0003(<0.05)$ and company size with a prob of $0.0002(<0.05)$ had a significant positive effect on company performance. While the age of the company with a probability of $0.4967(>0.05)$ has no significant effect on company performance. Governance does not moderate the effect of risk management on company performance with a probability of $0.8623(>0.05)$, does not moderate the influence of company age on company performance with a probability of 0.3949 ( $>0.05)$, and does not moderate the effect of firm size on company performance with probability of $0.0668(>0.05)$.
\end{abstract}

Keyword: Company Performance, Risk Management, Company Age, Company Size, Governance.

\section{A. INTRODUCTION}

Company performance is one of the benchmarks that companies use in making decisions and achieving the goals of an entity. By knowing the performance achievements, the company will know how much profit it has with the total assets it owns, equity, and debt. There are many factors that affect company performance such as the quality of human resources, the amount of budget, corporate culture, implementation of corporate governance, implementation of risk management, implementation of total quality management, company age, and company size. The factors that will be examined in this study are the influence of risk management implementation, company age, company size, and governance because these factors are considered to have a lot of influence on the performance of banking companies. Banking companies listed on the Indonesia Stock Exchange include Bank Mandiri, Bank Rakyat Indonesia, Bank Tabungan Negara, Bank Negara Indonesia, and so on.. 
The implementation of risk management is indispensable in banking activities to mitigate risks to the achievement of company performance in order to create better performance for the company. The application of risk management is not only intended to comply with applicable regulations in the field of risk management, but also because of the need for banks to manage banking risks that hinder the achievement of objectives.

Company age is also an important variable to drive company performance. The older the company is, the more productive capacity it should have, such as relationships with various parties. The learning process over a long period of time is thought to increase the company's maturity.

Company size shows the size of the company. The larger the company size, the greater its ability to carry out various company operations. A large size will increase the company's ability to produce and complete various company obligations. Company size (firm size) is the level or size of the company. Company size indicators can be translated into various measures such as the value of assets and the amount of capital. Muslih (2018) conducted a study on companies listed on the Indonesia Stock Exchange classified as LQ 45, finding that company size has a positive and significant effect on company performance.

The implementation of governance is also very important for banking companies. Putri \& Nasir (2006) state that corporate governance has a positive influence on company performance. Pranata (2007) in Maretha and Purwaningsih (2013) added that the implementation of GCG can significantly increase return on equity and net profit margin as an indicator of company performance.

Selcuk (2016) shows that companies that are still young show a decline in profitability from the start, but they may be profitable again in old age. Loderer and Urs (2010) in Khalid \& Nurlaili (2017) say that the older the company will decrease its profitability because the older the management company will decline, the bigger the board of directors, and the higher the CEO salary in the bigger companies.

The budget is a very important tool in designing effective short-term planning and control in organizations. Jermias and Yigit (2013) conducted a study in Turkey on budget participation in Turkey: the effect of information asymmetry, target commitment, and role ambiguity in job satisfaction and performance. The result of this study is that Turkey is an interesting place to investigate the impact of participation budgeting on job satisfaction and performance due to unique cultural and institutional factors.

\section{B. LITERATURE REVIEW}

\section{Agency Theory}

Jensen and Meckling (1976) state that agency theory is a theory that regulates the relationship between principals (shareholders) and agents (managers). The relationship between owner and manager must be arranged so that the manager will decide and act in the interests of the owners or shareholders. 


\section{Firm Performance}

Company performance is the goal of all business entities. Company performance is the result of management activities. Parameters that are often used to assess the performance of a company are carried out using an approach in which financial information is taken from financial reports or other financial reports. There are several definitions of performance. Company performance is the result or achievement achieved by management in carrying out its duties to develop effective company assets in one period (Rudianto, 2013 p.189).

\section{Risk Management}

According to Anastasya and Novita (2019) risk management is all systematic activities within the company in order to process uncertainty in the form of risk identification, risk mapping, risk measurement, risk control, risk monitoring, and risk management. Darmawi, (2014) adds that risk management is an effort to find out, analyze, and control risk in all company or entity activities aimed at getting a better level of effectiveness and efficiency.

\section{Firm Age}

According to Nugroho (2012), the age of a company is the origin of a company running operational activities until it is finally able to develop to a going concern and is able to survive in the market. The age of the company shows how long a company can maintain its existence on the stock exchange, Kartika (2009) in Nazir, et al. (2013). Febriani (2015) states that a company with a long life usually has developed into a company that is going concern, and has a large number of shareholders and is able to maintain it in the market, so that it is able to carry out intellectual capital disclosures.

\section{Firm Size}

According to Febriani (2015), company size is the size of a company. If the size of the company gets bigger, the company will be increasingly required to be transparent regarding information on the condition of the company, be it financial conditions or other conditions. According to Machfoedz (1994) company size is a scale grouped by the size of the company based on various ways.

\section{Corporate Governance}

According to Fahmi (2013 p.61) governance is a concept that has idealism in achieving the goals of shareholders. Stakeholders have the hope of getting the maximum profit on every investment they carry out. All decisions and policies designed by company management can have an influence on the company's performance, and of course it has an impact on the stock price in the market. Governance (corporate governance) is an arrangement in a stakeholder relationship with company managers. Governance (corporate governance) is very important because it is a key in agency problems (Muslih, 2018). Amir (2011) in Mardiyati and 
Wahyudi (2018) conveyed 5 principles of Good Corporate Governance, namely: transparency, independence, accountability, responsibility, and fairness.

\section{Budgeting}

According to Anthony and Govindarajan (2011 p. 91) the budget is an important tool for effective short-term planning and control in organizations. An operating budget normally covers one year and lists revenues and expenses for the planned time of year. Budget plays an important role in a company. In the budget, the activities to be carried out and the use of resources owned by the company are arranged. The role of managers in budgeting is very influential on company activities. So that managers are expected to be able to make decisions about budgeting.

\section{The Effect of Risk Management on Company Performance}

Risk management anticipates risks that may occur and seeks mitigation measures. Thus, anything that hinders the achievement of goals can be identified in advance and a solution is sought. So that the company's goals can be achieved. The company's goal is profit. Several previous studies have shown a relationship between the benefits of implementing enterprise risk management on company performance. Muslih (2018) also agrees that based on his research, risk management has a positive influence on company performance.

Based on the above discussion, the hypothesis can be formulated as follows: H1: Risk management has a positive effect on company performance.

\section{Effect of Company Age on Company Performance}

Company age is also an important variable in driving company performance. The older the company is, the more it will have to do with various parties. Rossi (2016) has conducted a literature study on the effect of company age on company performance. The results of his research show that previous studies still show variations in the results of research regarding the effect of company age on company performance. Different results are proven by Muslih (2018) that company age has a significant positive effect on performance.

Based on the results of the discussion above, the hypothesis is as follows: $\mathbf{H 2}$ : Company age has a positive effect on company performance.

\section{The Influence of Firm Size on Firm Performance}

Company size (firm size) is the level or size of the company. The company size indicator can be translated into various measures such as the value of assets and the amount of capital. Various studies have shown a relationship between company size and company profits. Aprianingsih and Yushita (2016) stated that company size has a significant positive effect on financial performance. From these studies, it is proven that company size has a significant positive effect on company performance. 
Based on the discussion above, the hypothesis is as follows: H3: Firm size has a positive effect on company performance.

\section{Governance Moderation on the Effect of Risk Management on Company Performance}

Governance is a set of rules arranged in a systemized manner that aims to regulate the relationship between principals, agents, creditors, government, employees, and other internal and external stakeholders who are related to rights and obligations in processes related to company control (Cadbury Committee of United Kingdom, 2008 in Tjandra, 2015). Arifin (2017) concluded from the results of his research that corporate governance has a significant effect on performance.

Based on the above discussion, the hypothesis is determined as follows: H4: Governance moderates the effect of risk management on company performance.

\section{Corporate Governance Moderates the Influence of Company Age on Company Performance}

Corporate governance is a set of rules that are structured in a systemized manner that aims to regulate the relationship between principals, agents, creditors, government, employees, and other internal and external stakeholders who are related to rights and obligations in processes related to company control (Cadbury Committee of United Kingdom, 2008 in Tjandra, 2015). According to Muslih (2019), it is concluded that corporate governance has an effect on company performance.

Based on the above discussion, the hypothesis is determined as follows: H5: Governance moderates the effect of risk management on firm performance.

\section{Corporate Governance Moderates the Influence of Firm Size on Firm Performance}

Corporate governance is a set of rules that are structured in a systemized manner that aims to regulate the relationship between principals, agents, creditors, government, employees, and other internal and external stakeholders who are related to rights and obligations in processes related to company control (Cadbury Committee of United Kingdom, 2008 in Tjandra, 2015). Rifai, et al. (2015) concluded from their research that corporate governance has a significant positive effect on company profitability.

Based on the above discussion, the hypothesis is as follows: H6: Governance moderates the effect of risk management on firm performance.

Based on the hypothesis that has been developed above, the research structure is as follows: 


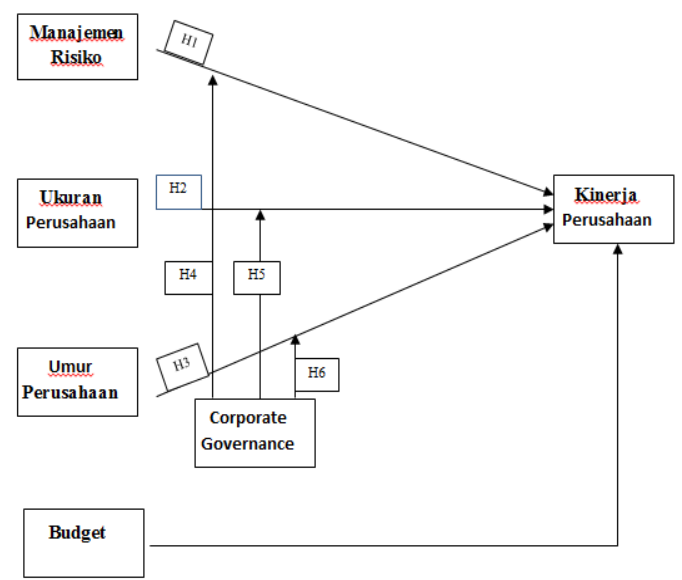

Figure 1 Research Structure

\section{METHOD}

This research uses quantitative methods. Data processing using Eviews 9 software. In this study, researchers used 6 variables consisting of 3 independent variables (independent variable), 1 dependent variable (dependent variable), 1 control variable, and 1 moderating variable.

Risk management (X1) is measured by looking at the achievement of its implementation. The purpose of using the Likert scale is to measure attitudes, opinions and understandings of individuals or groups about social phenomena. The stages of enterprise risk management that are measured in this study are as follows:

1. Event Identification

2. Risk Identification

3. Risk Analysis

4. Treatment of risks / risk mitigation

Company age (X2) is the length of time the company was founded and listed on the Indonesia Stock Exchange. The age of the company is calculated from the difference between the year of research and the year of recording or the year of IPO (first issue) on the IDX. The measurement of company age is done in the number of months. Company Size (X3) is the size of the company. The proxy used for company size is total assets. Governance (moderating variable) uses a measuring tool for the number of audit committees. Budget (control variable) in this research is budget (budgeting). Budget is the number of financing plans that the company will implement in one accounting period.

The population in this study are banking companies listed on the Indonesia Stock Exchange (BEI). The sampling technique used in this study was purposive sampling, which is a technique for taking samples based on certain criteria, not randomly, and according to the research objectives. The criteria for the companies sampled in this study are banking companies listed on the Indonesia Stock Exchange from 2013 to 2018.

The technique used in collecting research data is by reviewing annual reports and analyzing annual reports on banking companies listed on the Indonesia Stock 
Exchange through the official website www.idx.co.id and the company's official website. The research method used in this research is quantitative method. Data analysis to be carried out is a classic assumption test and hypothesis testing. The classical assumption test consists of normality test, multicolinearity test, autocorrelation test, and heteroscedasticity test. The hypothesis test consists of the coefficient of determination test, the $\mathrm{F}$ test, and the $\mathrm{t}$ test.

In this study, the hypothesis test was analyzed using multiple linear regression, using Eviews software as a data processing tool. The regression equation in this study is as follows:

\section{$\mathrm{Y}=\mathrm{a}+\mathrm{b} 1 \mathrm{MR}+\mathrm{b} 2 \mathrm{UMPER}+\mathrm{b} 3 \mathrm{UKPER}+\mathrm{b} 4 J K A M R P E R+b 5 J K A U M P E R+b 6 J K A U K P E R+b 7$ ANG+e}

Where:

$\mathrm{Y}=$ Firm Performance

a $=$ Constant

e $=$ Random Variable

$\mathrm{b}=$ Regression Coefficient for each independent variable

$\mathrm{X} 1$ = Risk Management

$\mathrm{X} 2=$ Age of the Firm

X3 = Firm Size

JKAMR = Moderation of Governance towards the Influence of Risk Management JKAUMPER = Moderation of Governance towards the Influence of the age of the Company X3CG $=$ Governance Moderation on The Infouence of Firm Size. $\mathrm{ANG}=$ Budget.

\section{RESULTS AND DISCUSSION}

The population of this research is banking companies listed on the Indonesia Stock Exchange. The financial reports used are annual financial reports that have been published on the website www.idx.co.id and the company's official website. The data in this study are the achievement of risk management implementation, the difference between the years of the study and the year the company was founded for the company's age, the total assets for the size of the company, the multiplication of the number of audit committees with risk management to moderate governance on the effect of risk management, the multiplication of the number of audit committees with the age of the company. for moderation of governance on the effect of firm age, multiply the number of audit committees by the total company assets for governance moderation on the effect of firm size, and total budget realization for control variables.

The research data passed the classical assumption test. The descriptive statistics of the research data are as follows:

\section{Table 1 Descriptive Statistics Results}




\begin{tabular}{|l|c|c|c|c|}
\hline & Max & Min & Mean & $\begin{array}{c}\text { Std. } \\
\text { Deviasi }\end{array}$ \\
\hline KP & 5.420 .000 & -11.115 .000 & 1.021071 & 2.382 .820 \\
\hline MR & 4.000000 & 1.000000 & 3.303 .571 & 0.715600 \\
\hline UMPER & 1476.000 & 4.127134 & 6.066 .798 & 0.590281 \\
\hline UKPER & 2.098 .324 & 1.339 .546 & 1.682 .866 & 2.003 .635 \\
\hline JKAMR & 3.600 .000 & 3.000 .000 & 1.278 .571 & 5.287 .136 \\
\hline JKAUMPER & 11424.00 & 2.480 .000 & 2030.071 & 1.813 .695 \\
\hline JKAUKPER & $7.78 E+09$ & 1971036 & $6.66 \mathrm{E}+08$ & $1.55 \mathrm{E}+09$ \\
\hline ANG & 71170000 & 22381.00 & 3232792 & 9009872 \\
\hline
\end{tabular}

Source: Statistical Results Processed By Eviews 9.

Multiple linear regression test shows the following results:

Table 2 T-Test Result

\begin{tabular}{|c|l|c|c|}
\hline No & \multicolumn{1}{|c|}{ Variable } & Coefficient & Prob \\
\hline 1 & MR & 1.174070 & 0.0003 \\
\hline 2 & UMPER & 0.440353 & 0.4967 \\
\hline 3 & UKPER & 0.454984 & 0.0002 \\
\hline 4 & JKAMR & -0.011067 & 0.8623 \\
\hline 5 & JKAUMPER & -0.000263 & 0.3949 \\
\hline 6 & JKAUKPER & $4.50 \mathrm{E}-10$ & 0.0668 \\
\hline 7 & ANG & $-4.55 \mathrm{E}-08$ & 0.1505 \\
\hline
\end{tabular}

Source: Statistical Result Processed By Eviews 9.

From the table above it can be seen that the adjusted R-squared is 0.334048 or $33 \%$. This means that from changes in variable $Y$, as much as $33 \%$ can be explained by changes in variable $X$. The results of the F test show Prob (F-Statistic) $0.000000<$ 0.05 is significant. This means that simultaneously the independent variable affects the dependent variable. It means that the research model is adequate for use in the decision making process.

Hypothesis test results show that the risk management coefficient (X1) 3.685101 with prob. $0.0003<0.05$ is significant. This means that the risk management variable has a positive and significant effect on company performance. Hypothesis 1 is accepted. Company age coefficient (X2) 0.681170 with prob. $0.4967>0.05$. Not significant. So it means that the age variable of the company does not have a significant effect on company performance. Hypothesis 2 is rejected. The coefficient of firm size (X3) 3.756219 with a probability of $0.0002<0.05$ is significant. So it means that the company size variable has a positive and significant effect on company performance. Hypothesis 3 is accepted. The moderation coefficient of governance in risk management (JKAMR) -0.173714 with a probability of $0.8623>0.05$. Not significant. This means that the governance variable does not moderate the effect of risk management on company performance. Hypothesis 4 is rejected. The moderation coefficient of governance on the influence of company age on company performance is -0.853041 with a probability of $0.3949>0.05$. Not significant. This means that governance does not moderate the influence of company age variables on 
company performance. The moderating variable coefficient of governance on firm size (JKAUKPER) is 1.845416 with a probability of $0.0668>0.05$. Not significant. This means that the governance variable does not influence the firm size variable on company performance. Budget coefficient (ANG) -1.444777 with prob $0.1505<0.05$. Not significant. So it means that the budget variable has no effect on company performance.

\section{Effect of Risk Management on Company Performance}

The results show that risk management has a positive and significant effect on the performance of banking companies listed on the Indonesia Stock Exchange from 2013 to 2018. This shows that the implementation of good risk management in a company will result in good company performance as well. By implementing risk management, all risks to the achievement of company goals can be anticipated in advance. Meanwhile, if risk management has not been implemented in a company, the company's performance will be difficult to develop.

Based on the results of this study, it turns out that risk management in banking companies has been implemented properly. The results of this study are in line with research conducted by Muslih (2018) which concluded that risk management has a significant positive effect on company performance. Indahsari, Rosdiana, and Lestari (2018) in their research concluded that the application of risk management has a significant positive effect on organizational performance in Islamic banking institutions in the city of Bandung.

\section{Effect of Company Age on Firm Performance}

Company age has no effect on the performance of banking companies listed on the Indonesia Stock Exchange in 2013-2018. The test results in this study indicate that the age of the company does not have a significant effect on company performance using a proxy for the number of company ages converted into months. This shows that the older the company is, the company's performance will decline.

The results of this study support the results of the research by Cardila et al. (2018) that there is a negative effect of company age on company performance. Satoto (2009) concluded from the results of his research that company age had a negative effect on company performance.

\section{The Effect of Company Size on Firm Performance}

The regression test results show that company size has a significant positive effect on the performance of banking companies listed on the Indonesia Stock Exchange from 2013 to 2018. This phenomenon shows that the bigger the size of a company, the better its performance.

The results of this study support the research conducted by Aprianingsih and Yushita (2016) that company size has a significant positive effect on financial performance and Dogan (2013) that company size has a positive influence on company performance. 


\section{Governance Moderates the Effect of Risk Management on Firm Performance}

Governance does not moderate the effect of risk management on company performance. This means that corporate governance does not strengthen or weaken the effect of risk management on the performance of banking sector companies listed on the Indonesia Stock Exchange from 2013 to 2018. The level of implementation of corporate governance does not strengthen the effect of risk management on company performance. According to some research results, corporate governance should be able to improve company performance. Muslih (2018) states that corporate governance is a rule of the relationship between company owners and company agents, which aims to increase company profits.

The results of this study are in line with the results of research conducted by Muslih (2018) which concluded that corporate governance has an effect on company performance.

\section{Governance Moderates the Effect of Firm Age on Firm Performance}

Governance does not moderate the effect of company age on company performance. This means that governance does not strengthen the influence of company age on the performance of banking sector companies listed on the Indonesia Stock Exchange from 2013 to 2018. This may occur because governance has not been optimally implemented within the company.

The results of this study are in line with research conducted by Ekshandy (2018) which states that governance using audit committee proxies has a negative effect on financial performance.

\section{Governance Moderates the Effect of Firm Size on Firm Performance}

Governance does not moderate the effect of company size on company performance. Moderation of governance does not in fact strengthen the influence of company size on the performance of banking sector companies listed on the Indonesia Stock Exchange from 2013 to 2018.

This may be the case that governance has not been optimally implemented within the company. In agency theory, management is expected to run the company's operating system in the best interest of the company owner. Managers will manage all company assets optimally so as to increase company profits. However, it turns out that based on the results of research, governance moderation on the effect of firm size on company performance is not effective. The results of this hypothesis are in line with research conducted by Cardilla, et al. (2019) and Epi (2017), which show that company size has no effect on company performance.

\section{Effect of Budget on Company Performance}

Budget (budgeting) has no effect on company performance. This means that the budget has no effect on the performance of banking companies listed on the 
Indonesia Stock Exchange from 2013 to 2018. This may occur because the budget has not been managed optimally.

This research result is in line with research conducted by Muslih (2013) that budget has a negative effect on company performance. Sholikah, Hidayati, and Mawardi (2019) found in their research that the budget has a negative effect on firm performance.

\section{E. CONCLUSION}

Risk management has a significant positive effect on the performance of banking companies listed on the Indonesia Stock Exchange in 2013-2018. This is evidenced by the coefficient value of 1.174070 and a prob of 0.0003 which is below 0.05 (significance level $\mathrm{a}=0.05$ ). So that the first hypothesis is proven. Company age has a negative effect on the performance of banking companies listed on the Indonesia Stock Exchange in 2013 - 2018. This is evidenced by the coefficient value of 0.440353 and a prob of 0.4967 which is above 0.05 (significance level $\mathrm{a}=0.05$ ). The second hypothesis is not proven.

Company size has a significant positive effect on the performance of banking companies listed on the Indonesia Stock Exchange from 2013 to 2018. This is evidenced by the coefficient value of 0.454984 and prob of 0.0002 which is below 0.05 (significance level $\mathrm{a}=0.05$ ). The third hypothesis is proven. Governance does not moderate the effect of risk management on the performance of companies listed on the Indonesia Stock Exchange in 2013 - 2018. This is evidenced by the coefficient value of -0.011067 and a prob of 0.8623 which is above 0.05 (significance level $\mathrm{a}=$ 0.05). The fourth hypothesis is not proven.

Governance does not moderate the effect of company age and has a negative and insignificant effect on the performance of banking companies listed on the Indonesian Stock Exchange in 2013-2018. a = 0.05). The fifth hypothesis is not proven. Governance does not moderate the effect of company size on the performance of banking companies listed on the Indonesia Stock Exchange in 2013-2018. This is evidenced by the coefficient value of $-4.50 \mathrm{E}-10$ and a prob of 0.0668 which is above 0.05 (significance level $\mathrm{a}=0.05$ ). The sixth hypothesis is not proven. The budget has no effect on the performance of banking companies listed on the Indonesia Stock Exchange from 2013 to 2018.

\section{REFERENCES}

1. Ahmad, S., Ng, C., \& McManus, L. (2014). Enterprise Risk Management (ERM) Implementation: Some Empirical Evidence from Large Australian Companies. International Conference on Accounting Studies, Kuala Lumpur, Malaysia.

2. Akben-Selcuk, E. (2016). Does Firm Age Affect Profitability? Evidence from Turkey. International Journal of Economic Sciences, (3), 1-9.

3. Amato, L. H., \& Burson, T. E. (2007). The Effects of Firm Size on Profit Rates in The Financial Services. Journal of Economics and Economic Education Research, 8(1), 2007. 
4. Anthony, N. R., \& Govindarajan, V. (2011). Sistem Pengendalian Manajemen. Tangerang: Karisma Publishing Group.

5. Aprianingsih, A., \& Yushita, A. N. (2016). Pengaruh Penerapan Good Corporate Governance, Struktur Kepemilikan, dan Ukuran Perusahaan Terhadap Kinerja Keuangan Perbankan.

6. Arifin, J. (2017). Pengaruh Corporate Governance Terhadap Kinerja Keuangan Sub Sektor yang Terdaftar pada Bursa Efek Indonesia Periode 2008 - 2012, 1(1).

7. Banjarnahor, D., \& Muslih, M. (2019). Tata Kelola Berkelanjutan untuk Meningkatkan Kinerja BUMN Perbankan yang Terdaftar di Bursa Efek Indonesia yang Masuk Klasifikasi LQ 45.

8. Callahan, C., \& Soileau, J. (2017). Does Enterprise Risk Management Enhance Operating Performance? Advances in Accounting.

9. Cardilla, A. L., Muslih, M., \& Rahadi, D. R. (2019). Pengaruh Arus Kas Operasi, Umur Perusahaan, Dan Ukuran Perusahaan Terhadap Kinerja Perusahaan Perbankan Yang Terdaftar Di Bursa Efek Indonesia Periode 2011-2016. Firm Journal of Management Studies, 4(1), 66.

10. Chang, C. L., Hsu, H. K., \& McAleer, M. (2013). Is Small Beautiful? Size Effects of Volatility Spillovers for Firm Performance and Exchange Rates in Tourism. North American Journal of Finance and Economics.

11. Commission, C. of S. O. of the T. (2004). Enterprise Risk Management-Integrated Framework Executive Summary. New York.

12. Dafikpaku, E. (2011). The Strategic Implications of Enterprise Risk Management: A Framework. Enterprise Risk Management Symposium, 49.

13. Darmawan, \& Abdi, D. (2017). Pengembangan Metode Peningkatan Kualitas Laporan Keuangan Pada PT Pelabuhan Indonesia Iv Berbasis Good Corporate Governance Di Kota Parepare. Jurnal Ekonomi Pembangunan STIE Muhammadiyah Palopo, 3(2), 109-117.

14. Dewa, D. F. H., Mahsuni, A. W., \& Junaidi. (2020). Analisis Pengaruh Corporate Social Responsibility (CSR), Profitabilitas, Kinerja Perusahaan, dan Kualitas Audit Terhadap Integritas Laporan Keuangan (Studi Empiris pada Perusahaan Manufaktur yang Terdaftar di BEI Tahun 2016-2018). E-Jra, 08(09), 1-13.

15. Dinçer, H., Hacıoğlu, Ü., \& Yüksel, S. (2017). Balanced Scorecard Based Performance Measurement Of European Airlines Using A Hybrid Multicriteria Decision Making Approach Under The Fuzzy Environment. Journal of Air Transport Management, 63, 17-33.

16. Doğan, M. (2013). Does Firm Size Affect The Firm Profitability ? Evidence from Turkey. Research Journal of Finance and Accounting, 4(4), 53-60.

17. Eksandy, A. (2018). Pengaruh Good Corporate Governance Terhadap Kinerja Keuangan Pada Perbankan Syari'Ah Indonesia. Jurnal Akuntansi: Kajian Ilmiah Akuntansi (JAK), 5(1), 1.

18. Epi, Y. (2017). Pengaruh Ukuran Perusahaan, Struktur Kepemilikan Manajerial dan Manajemen Laba Terhadap Kinerja Perusahaan Property dan Real Estate. Jurnal Riset Akuntansi, 1(1), 1-7. 
19. Esa, N. P. K., Pratiwi, Y. E., \& Perdana, B. C. (2020). Management Control System Analysis On Offical Travel Costs at PT. Global Medik Persada (Glomeda). Journal of Economy, Accounting and Management Science, 1(2), 42-49.

20. Fachrudin, K. A. (2011). Analisis Pengaruh Struktur Modal, Ukuran Perusahaan, dan Agency Cost Terhadap Kinerja Perusahaan. Jurnal Akuntansi dan Keuangan, 13(1), 37-46.

21. Fahmi, I. (2013). Analisis Laporan Keuangan. Bandung: Alfabeta.

22. Febriani, S. L. (2015). Pengaruh Ukuran Perusahaan, Umur Perusahaan, dan Karakteristik Good Corporate Social Responsibility Disclosure.

23. Florio, C., \& Leoni, G. (2016). Enterprise Risk Management and Firm Performance: The Italian Case. British Accounting Review, 49(1), 56-74.

24. Gaur, V., \& Kesavan, S. (2015). The Effects of Firm Size and Sales Growth Rate on Inventory Turnover Performance in the U.S. Retail Sector. International Series in Operations Research and Management Science, 25-52.

25. Ghozali, I., \& Ratmono, D. (2013). Analisis Multivariant dan Ekonometrika: Teori, Konsep dan Aplikasi dengan Eviews 8. Semarang: Undip.

26. Herry. (2017). Teori Akuntansi Pendekatan Konsep dan Analisis. Jakarta: Grasindo.

27. Hoyt, R. E., \& Liebenberg, A. P. (2011). The Value of Enterprise Risk Management. Journal of Risk and Insurance, 78(4), 795-822

28. Ikatan Bankir Indonesia. (2015). Manajemen Risiko 1. Jakarta: Gramedia Pustaka Utama.

29. Indahsari, R., Rosdiana, Y., \& Lestari, R. (2018). Pengaruh Penerapan Manajemen Risiko Terhadap Kinerja Organisasi pada Lembaga Perbankan Syariah di Kota Bandung, 19(1), 37-43.

30. Indarto, S. L., \& Ayu, S. D. (2011). Pengaruh Partisipasi dalam Penyusunan Anggaran terhadap Kinerja Manajerial Perusahaan Melalui Kecukupan Anggaran, Komitmen Organisasi, Komitmen Tujuan Anggaran, dan Job Relevant Information (JRI). Seri Kajian Ilmiah, 14(1), 32-44.

31. Jensen, M. C., \& Meckling, W. H. (1976). Theory of the Firm: Managerial Behavior, Agency Costs and Ownership Structure. Corporate Governance: Values, Ethics and Leadership, 3(4), 305-360.

32. Jermias, J., \& Yigit, F. (2013). Budgetary Participation in Turkey: The Effects of Information Asymmetry, Goal Commitment, and Role Ambiguity on Job Satisfaction and Performance. Journal of International Accounting Research, 12(1), 29-54.

33. Kamal, M. B. (2016). Pengaruh Receivable Turn Over dan Debt to Asset Ratio (DAR) Terhadap Return on Asset (ROA) pada Perusahaan Pertanian yang Terdaftar Di Bursa Efek Indonesia (BEI). Jurnal Ilmiah Manajemen Dan Bisnis, 17(2), 68-81.

34. Kanhai, C., \& Ganesh, L. (2014). Factors Influencing The Adoption Of Enterprise Risk Management (ERM) Practices by Banks in Zimbabwe. International Journal of Business and Commerce, 3(6), 1-17. 
35. Khafid, M., \& Nurlaili, D. (2017). The Mediating Role of Accountability in the Influence of Cooperative Characteristics on Its Financial Performance. International Journal of Economic Research, 14(5), 191-200.

36. King, R., Clarkson, P. M., \& Wallace, S. (2010). Budgeting Practices and Performance in Small Healthcare Businesses. Management Accounting Research, 21(1), 40-55.

37. Kumaş, H., Çağlar, A., \& Karaalp, H. S. (2014). Firm Size and Labour Market Segmentation Theory: Evidence from Turkish Micro Data. Procedia - Social and Behavioral Sciences, 150, 360-373.

38. Kurniawati, I. (2009). Pengaruh Partisipasi Anggaran, Teknologi Informasi terhadap Kinerja Perusahaan.

39. Latifah. (2016). Analisis Pengaruh Motivasi Kerja Terhadap Kinerja dengan Kepuasan Kerja sebagai Variabel Intervening. Jurnal Khatulistiwa Informatika, 4(1), 52-64.

40. Linton, G., \& Kask, J. (2016). Configurations of Entrepreneurial Orientation And Competitive Strategy For High Performance. Journal of Business Research.

41. Liu, J. (2012). The Enterprise Risk Management and the Risk Oriented Internal Audit. IBusiness, 04, 287-292.

42. Lubis, I. P., Fujianti, L., \& Amyulianthy, R. (2018). Pengaruh Ukuran KAP, Ukuran Perusahaan dan Manajemen Laba terhadap Integritas Laporan Keuangan. ULTIMA Accounting, 10(2), 138-149.

43. Mangkunegara, A. A. P. (2000). Manajemen Sumber Daya Manusia Perrusahaan. Bandung: Remaja Rosda Karya.

44. Manik, E. (2014). Pengaruh Komitmen Organisasi, Budaya Organisasi dan Kepemimpinan terhadap Tata Kelola Perusahaan serta Implikasinya pada Kinerja Keuangan Perusahaan. Kontigensi: Scientific Journal of Management, 2(1), 10-16.

45. Mardiyati, \& Wahyudi, H. (2018). Penerapan Prinsip GCG (Transparansi dan Akuntabilitas) dalam Kerangka Laporan Keuangan Kelompok Pemodal 13 di Pontianak Timur. Jurnal Ekonomi STIEP, 3(2), 24-30.

46. Maretha, N., \& Purwaningsih, A. (2013). Pengaruh Penerapan Good Corporate Governance Terhadap Kinerja Perusahaan. Jurnal Akuntansi Bisnis, 14(9), 1667.

47. Menteri Keuangan. 2009. Peraturan Menteri Keuangan No 142/PMK.010/2009 tentang pembentukan Komite Pemantau Resiko. MENKEU. Jakarta.

48. Mcbride, E. P. (2012). Enterprise Risk Management: Framework Presence and Effectiveness How Has Open Access to Fisher Digital Publications Benefited You? Enterprise Risk Management : Framework Presence and Effectiveness.

49. Muslih, M. (2019). Pengaruh Kompensasi Komisaris dan Direksi Terhadap Laba.

50. Muslih, M. (2019). Tata Kelola Berkelanjutan Bagi BUMN Bidang Keuangan Non Publik, 4(2).

51. Muslih, M. (2018). The Benefit of Enterprise Risk Management.

52. Muslih, M. (2018). The Influence of Budgeting System, Organizational Culture, And Firm Size To Performance. Firm Journal of Management Studies, 3(2). 
53. Muslih, M., Rahadi, D. R., \& Marbun, S. O. (2019). Tata Kelola Pemerintahan Berkelanjutan Untuk Meningkatkan Kinerja Pemerintah Daerah.

54. Muslih, M., \& Sugianti, I. (2019). Sistem Manajemen Kinerja Berbasis Balanced Scorecard dan Tata Kelola Pemerintahan pada Pemerintah Daerah.

55. Nasir, A., Kurnia, P., \& Hakri, T. D. (2013). Pengaruh Kepemilikan Manajerial, Leverage, Profitabilitas, Ukuran, dan Umur Perusahaan terhadap Pengungkapan Informasi Pertanggungjawaban Sosial Perusahaan pada Perusahaan Food and Beverage yang Terdaftar di BEI. Jurnal Ekonomi Universitas Riau, 21(04).

56. Nugroho, A. (2012). Faktor-Faktor Yang Mempengaruhi Intellectual Capital Disclosure (ICD). Accounting Analysis Journal, 1(2).

57. Nuswandari, C. (2009). Pengaruh Corporate Governance Perception Index Terhadap Kinerja Perusahaan Pada Perusahaan Yang Terdaftar Di Bursa Efek Jakarta. Jurnal Bisnis dan Ekonomi (JBE), 16(2), 70-84.

58. Oktamawati, M. (2017). Pengaruh Karakter Eksekutif, Komite Audit, Ukuran Perusahaan, Leverage, Pertumbuhan Penjualan, Dan Profitabilitas Terhadap Tax Avoidance. Jurnal Akuntansi Bisnis, 15(1), 23-40.

59. Onasis, K., \& Robin. (2016). Pengaruh Tata Kelola Perusahaan Terhadap Nilai Perusahaan pada Perusahaan Sektor Keuangan yang Terdaftar di BEI, 20(1), 1-22.

60. Pamungkas, A. S., \& Maryati, S. (2017). Pengaruh Enterprise Risk Management Disclosure, Intelectual Capital Disclosure, dan Debt to Asset Ratio Terhadap Nilai Perusahaan. Prosiding Seminar IIB Darmajaya, 412-428.

61. Pamungkas, A. (2019). Pengaruh Penerapan Enterprise Risk Management (COSO) Terhadap Nilai Perusahaan: Studi Empiris pada Perusahaan Manufaktur yang Terdaftar, 11, 12-21.

62. Prasinta, D. (2012). Pengaruh Good Corporate Governance Terhadap Kinerja Keuangan Perusahaan pada Perusahaan yang Terdaftar Dalam Corporate Governance Perception Index Tahun 2006-2010.

63. Puspitasari, B., \& Hartono, U. (2016). Pengaruh Ukuran Dewan Direksi, Ukuran Komite Audit dan Ukuran Perusahaan Terhadap Kinerja Perusahaan. Jurnal Ilmu Manajemen, 21-26.

64. Putra, I. G. A. P., \& Ramantha, I. W. (2015). Pengaruh Profitabilitas, Umur Perusahaan, Kepemilikan Institusional, Komisaris Independen, Dan Komite Audit Pada Ketepatwaktuan Publikasi Laporan Keuangan Tahunan. E-Jurnal Akuntansi, 10(1), 199-213.

65. Putri, I. F., \& Nasir, M. (2006). Analisis Persamaan Simultan Kepemilikan Manajerial, Kepemilikan Institusional, Risiko, Kebijakan Hutang dan Kebijakan Dividen dalam Perspektif Teori Keagenan. Simposium Nasional Akuntansi 9 Padang, 23-26.

66. Republic of Indonesia Law Number 8 of 1997 concerning Company Documents.

67. Rifai, M., Arifati, R., \& Maria, M. (2015). Pengaruh Ukuran Perusahaan, Struktur Modal, dan Pertumbuhan Perusahaan terhadap Profitabilitas (Studi pada Perusahaan Manufaktur di BEI tahun 2010-2012). 
68. Rossi, M. (2016). The Impact of Age on Firm Performance: A Literature Review. Corporate Ownership and Control, 13(2), 217-223.

69. Rudianto. (2013). Akuntansi Manajemen. Jakarta: Erlangga.

70. Saptari, S. D. (2016). Pengaruh Umur Perusahaan, Ukuran perusahaan, dan Operating Leverage Terhadap Struktur Modal (Studi Pada Perusahaan Makanan dan Minuman yang Terdaftar di Bursa Efek Indonesia Tahun 2010-2014).

71. Sari, V. P. M., Widarno, B., \& Sunarko, M. R. (2017). Pengaruh Penganggaran Partisipatif Terhadap Kinerja Manajerial dengan Karakteristik Sistem Akuntansi Manajemen sebagai variabel Moderasi (Survei pada Pegawai Satuan Kerja Perangkat Daerah Kabupaten Sragen), 13(2), 276-287.

72. Satoto, S. H. (2009). Strategi Diversifikasi Terhadap Kinerja Perusahaan. Jurnal Keuangan Dan Perbankan, 13(2), 280-287.

73. Sembiring, M. (2019). Analisis Rasio Likuiditas, Profitabilitas, Solvabilitas Dan Persediaan Untuk Menilai Kinerja Perusahaan Retail Yang Terdaftar Di BEI. Jurnal Akuntansi Barelang, 4(1), 75-85.

74. Setiadewi, K. A. Y., \& Purbawangsa, I. B. A. (2015). Pengaruh Ukuran Perusahaan dan Leverage terhadap Profitabilitas dan NIlai Perusahaan, 596-609.

75. Shivashankarappa, A. N., Ramalingam, D., Smalov, L., \& Anbazhagan, N. (2011). An Exploratory Study Of ERM Perception In Oman And Proposing A Maturity Model For Risk Optimization. Proceedings of the 9th Australian Information Security Management Conference, 1(1), 215-222.

76. Sholikah, I., Hidayati, N., \& Mawardi, M. C. (2019). Pengaruh Partisipasi Penyusunan Anggaran Terhadap Kinerja Pemerintah Daerah dengan Komitmen Organisasi sebagai Variabel Moderating.

77. Siallagan, H., \& Machfoedz, M. (2006). Mekanisme Corporate Governance, Kualitas Laba dan NIlai Perusahaan. Simposium Nasional Akuntansi 9 Padang.

78. Sijabat, J. (2019). Pengaruh Karakteristik Perusahaaan Terhadap Kualitas Laporan Keuangan (Study Empiris pada Perusahaan Manufaktur yang Terdaftar di Bursa Efek Indonesia Periode 2015-2018), 1-44.

79. Simamora, H. (2004). Manajemen Sumber Daya Manusia. Yogyakarta: STIE YKPN.

80. Sugiono. (2016). Metode Penelitian Kuantitatif, Kualitatif dan RED. Bandung: PT Alfabet.

81. Suwanda, W., \& Pratiwi, D. (2018). Laporan Keuangan Sebagai Bentuk Transparansi Pengelolaan Anggaran Ipdn Kampus Kalimantan Barat. Jurnal Ilmu Pemerintahan Suara Khatulistiwa, 3(1), 51-66.

82. Syafriyanti, L., Tanjung, A. R., \& Darlis, E. (2019). Pengaruh Partisipasi Anggaran Terhadap Kinerja Aparat Pemda: Kepemimpinan, Komitmen Organisasi, Desentralisasi, Budaya Organisasi Sebagai Moderating. Journal of Chemical Information and Modeling, 1(1), 1689-1699.

83. Tjandra, E. (2015). Pengaruh Good Corporate Governance Terhadap Leverage dan Profitabilitas Pada Perusahaan Property dan Real Estate di Indonesia, 4(2), 74-85.

84. Tseng, C. Y. (2007). Internal Control, Enterprise Risk management, and Firm Performance. 
85. Utomo, R. (2015). Pengaruh Profitabilitas, Komitmen Pimpinan Perusahaan, Leverage, Ukuran Perusahaan, dan Ukuran Dewan Komisaris terhadap Pengungkapan Corporate Social Responsibility (CSR) pada Perusahaan Manufaktur yang Terdaftar di BEI Tahun 2011-2013.

86. www.idx.com 